\title{
Stosunki azerbejdżańsko-ormiańskie w latach 1918-1920 w świetle opinii historyka Yakuba Mahmudova
}

$\mathrm{W}$ ydarzenia ostatnich dwudziestu lat XX wieku, w tym okres pierestrojki w Związku Socjalistycznych Republik Radzieckich, zapoczątkowany ogłoszeniem suwerenności przez Estońską SRR 16 listopada 1988 r. i zakończony deklaracją o samorozwiązaniu ZSRR uchwaloną przez Radę Najwyższą ZSRR 26 grudnia 1991 r., spowodował ożywienie ruchu narodowego w republikach radzieckich w Europie Wschodniej, w Azji Środkowej, na Kaukazie. W sumie piętnaście republik ZSRR ogłosiło suwerenność, wystąpiło ze Związku Radzieckiego i stało się niepodległymi państwami. Wśród nich znalazł się również w1991 r. Azerbejdżan (Republika Azerbejdżanu), zajmujący ważne miejsce w stosunkach międzynarodowych, w tym w kontaktach z Unią Europejską, również historycznie niezwykle bliski Polakom.

Azerbejdżan, podobnie zresztą jak i inne republiki z tej piętnastki, zamiast pełnić pierwotnie przypisaną mu rolę demokratycznego zaplecza pierestrojki, począł skupiać element antykomunistyczny, wzmacniając pozycję nie tylko przeciwników ustroju radzieckiego, ale i samego państwa w jego dotychczasowej formie ${ }^{134}$.

Unia Europejska już od 1996 r. pracowała nad zacieśnianiem stosunków z Republiką Azerbejdżanu( Umowa o partnerstwie i współpracy). Doskonałym przykładem obopólnie korzystnej współpracy jest strategiczne partnerstwo energetyczne ustanowione w 2006 roku. W 2010 r. Bruksela rozpoczęła negocjacje w sprawie układu stowarzyszeniowego. Energetyka nie jest jedynym polem rozwoju wzajemnych relacji. Stosunki Unii Europejskiej z Azerbejdżanem, w kontekście partnerstwa wschodniego, opierają się na zróżnicowanym podejściu, tj. Azerbejdżan ma swobodę wyboru, w jakim zakresie będzie korzystać z unijnej oferty stowarzyszenia politycznego i integracji gospodarczej oraz wdrażania głębokiej demokracji. Umacniające współpracę okazało się 14. posiedzenie Rady Współpracy UEAzerbejdżan z 9 grudnia 2013 r., gdyż już 1 września 2014 r. weszły w życie umowa UEAzerbejdżan o ułatwieniach $\mathrm{w}$ wydawaniu wiz oraz umowa UE-Azerbejdżan o readmisji osób przebywających nielegalnie. Następnie 14 listopada 2016 r. Rada przyjęła mandat negocjacyjny w sprawie kompleksowej umowy z Azerbejdżanem, zastępującą tę z 1996 roku. Ta miałaby lepiej wykazywać wspólne cele i wyzwania stojące wówczas przed UE i Azerbejdżanem. Do negocjacji doszło 7 lutego 2017 r., nazajutrz po wizycie prezydenta İlhama Aliyeva w Brukseli. 11 lipca 2018 r. UE i Azerbejdżan uzgodnili nowe priorytety partnerstwa. To był istotny krok w rozwijaniu stosunków UE z Azerbejdżanem, gdyż wspólne

${ }^{134}$ Yagub Mahmudov, Azerbaijan, Short History of Statehood, Baku 2006, s. 122-152. 
priorytety miały kształtować i wzmacniać kontakty. 9 lutego 2018 r. miało miejsce 15. posiedzenie Rady Współpracy UE-Azerbejdżan. Odbyło się w kontekście pogłębiania relacji. 4 kwietnia 2019 r. zwołano 16. posiedzenie Rady Współpracy UE-Azerbejdżan, na którym Rada wypracowała intensywniejsze relacje dwustronne ${ }^{135}$ Ta ścisła wielostronna współpraca powoduje, że polityka zagraniczna i wewnętrzna Republiki Azerbejdżanu nigdy dla UE nie była obojętna. $Z$ uwagą śledzi antagonizmy ormiańsko-azerbejdżańskie na tle przynależności Górskiego Karabachu, tłumione przez lata rządów radzieckich, a które wybuchły z nową siłą w 1988 r., gdy 13 lutego, w Stepanakercie, stolicy Górskiego Karabachu, rozpoczęły się manifestacje karabaskich Ormian, którzy domagali się przyłączenia tego regionu do Armenii $^{136}$. W czerwcu 2019 r. ${ }^{137}$ w Waszyngtonie odbyło się kolejne już spotkanie ministrów spraw zagranicznych Armenii i Azerbejdżanu, poświęcone uregulowaniu trwającego od trzydziestu lat konfliktu zbrojnego o Górski Karabach. Amerykańska dyplomacja oraz Unia Europejska mają zamiar pomóc w doprowadzeniu do pokoju na Kaukazie. Azerbejdżan ma nadzieję, że długotrwała walka o Górski Karabach, jako historycznie należący do niego, wróci do macierzy.

Historia konfliktu sięga XIX wieku. Wówczas to, na mocy traktatów w Gulistanie i Turkmanczaju, kończących dwie kolejne wojny rosyjsko-perskie z lat 1804-1813 oraz 18261828, wschodnie Zakaukazie przyłączono do Imperium Rosyjskiego. Szczególnie po 1828 r. już do rosyjskiego Azerbejdżanu zaczęła napływać ludność odmienna etnicznie od rdzennych mieszkańców (Azerów). Najliczniejszą grupę stanowili Ormianie, w drugiej kolejności Gruzini, Rosjanie i przedstawiciele innych słowiańskich narodów Rosji. Największe znaczenie miała imigracja ormiańska. Tylko w latach 1828-1830 na ziemie azerskie napłynęło 120 tys. Ormian, wyjeżdżających z Persji i Imperium Osmańskiego. Rozwój gospodarczy Azerbejdżanu rosyjskiego, związany z zapoczątkowanym w 1872 r. boomem naftowym w regionie Baku, spowodował osiedlania się w mieście także przybyszów spoza Imperium Rosyjskiego. Kolejna znacząca grupa emigrantów ormiańskich pojawiła się w Azerbejdżanie rosyjskim po wydarzeniach w Anatolii Wschodniej w końcu XIX wieku. Jak powszechnie wiadomo, władze carskie popierały napływ Ormian do Azerbejdżanu, namiestnicy Kaukazu w swojej polityce narodowościowej faworyzowali tę grupę etniczną kosztem miejscowych muzułmanów. Według Yakuba Mahmudova, w tej sytuacji Ormianie zaczęli z czasem postrzegać Azerbejdżan jako terytorium należne im ze względów historycznych (część Wielkiej Armenii), a zarazem część niepodległego państwa narodu ormiańskiego, które zamierzali zbudować. Narodowy ruch ormiański rozwijał się dynamicznie, w 1890 r. utworzona została Armeńska Federacja Rewolucyjna (Dasznakcutiun, dasznacy), łącząca program emancypacji narodowej z postulatami socjaldemokratycznymi. Partia ta początkowo uznawała za swojego głównego wroga Imperium Osmańskie, jednak już po kilku latach od powstania zwróciła się przeciwko carskiej Rosji pod wpływem polityki

\footnotetext{
${ }^{135} \mathrm{https}: / /$ www.consilium.europa.eu/pl/policies/eastern-partnership/azerbaijan/.

136 Wystąpienia poparł 19 lutego 1988 r. masowy wiec ludności w Erywaniu. 28 lutego 1988 r. doszło do manifestacji antyormiańskich w Sumgaicie, w trakcie których domagano się pozostawienia Górskiego Karabachu pod zwierzchnictwem Azerbejdżanu. Pokojowe manifestacje szybko zamieniły się w rozruchy narodowościowe* [D.Ch.].

${ }^{137}$ ttps://warsawinstitute.org/pl/gorski-karabach-bez-widokow-na-przelom/.
} 
namiestnika Kaukazu, Grigorija Golicyna ${ }^{138}$, który podjął działania na rzecz rusyfikacji szkół ormiańskich i przeciwko Kościołowi ormiańskiemu.

Wydarzenia polityczne i gospodarcze doprowadziły do powstania napięć, gdyż dążenia ormiańskie spotykały się z negatywnym odzewem rdzennej, muzułmańskiej ludności - Azerów, których sytuacja ekonomiczna pogarszała się jako że byli oni z reguły mieszkańcami wsi lub robotnikami pracującymi u Ormian, zajmujących się przede wszystkim handlem i mieszkających w miastach. Starcia ormiańsko-azerskie w 1905 r. były pierwszymi krwawymi walkami między Ormianami i Azerami na terenie Azerbejdżanu rosyjskiego. Gdy wybuchły, w regionie trwały już wystąpienia robotników bakijskich, rozpoczęte przez strajk generalny 13/26 grudnia 1904 roku.

Walki między Ormianami i Azerami rozpoczęły się w lutym 1905 r. w Baku, następnie rozlały się na pozostałą część Zakaukazia, wszędzie tam, gdzie muzułmanie i Ormianie żyli obok siebie. Podczas czterodniowych walk do najkrwawszych zajść doszło w Baku, Nachiczewanie i na terenie Górskiego Karabachu. Według różnych szacunków ofiarami zamieszek padło od trzech tysięcy do dziesięciu (a nawet kilkunastu) tysięcy osób, z czego większość była Azerami (muzułmanami) ${ }^{139}$. Całkowicie zniszczono 158 wsi zamieszkanych przez muzułmanów.

Jesienią 1905 r. Azerowie powołali do życia tajną organizację Obrona (Difai). Deklarowała ona walkę z Rosją, tworzyła również oddziały, które miały bronić Azerów przed atakami ze strony Ormian.

Podkreślić należy, że azersko-ormiański konflikt etniczny lat 1905-1907 odegrał, obok dyskusji o azerskim języku literackim, decydującą rolę w procesie kształtowania się azerskiej tożsamości narodowej.

Republika Armenii, utworzona na terenach Azerbejdżanu przekazanych jej w porozumieniu z dowództwem wojskowym oddziałów tureckich na Kaukazie Południowym przez rząd Republiki Azerbejdżanu na podstawie zasady „rzeczywistego osadnictwa”, próbowała przejąć kontrolę nad wszystkimi ujezdami i okręgami guberni erywańskiej i gandżyjskiej, gdzie w latach trzydziestych XIX wieku mieszkali Ormianie, nawet jeśli byli tam w wyraźnej mniejszości. Omijając prawomocne środki, Armenia wolała rozwiązać problem na drodze wojennej. Dlatego od 2. połowy 1918 r. aż do jesieni 1920 r. Armenia była w stanie wojny z Azerbejdżanem, której celem było uzyskanie kontroli nad regionem Karabachu, Zangezuru, Nachiczewanu, Szarur-Daralagezu, Gazachu - terenach, na których liczebność ludności muzułmańskiej była kilkakrotnie wyższa od ormiańskiej ${ }^{140}$.

Na obecne stosunki azerbejdżańsko-ormiańskie rzutują silnie wydarzenia z początku XX wieku, m.in. z lat 1905-1907, czyli z okresu starć i pogromów na tle etnicznym, jaki miał miejsce na terenach rosyjskiego Azerbejdżanu (wschodnie Zakaukazie) w czasie rewolucji 1905 roku. W prasie międzynarodowej wydarzenia w rosyjskim Azerbejdżanie były przedstawiane w sposób wyraźnie przychylny dla Ormian . O ile przed rokiem 1918 termin „Górski Karabach” miał znaczenie jedynie geograficzne, o tyle wraz z powstaniem

\footnotetext{
${ }^{138}$ Donald Rayfield, Edge of Empires. A History of Georgia, Reaktion Books, 2012, s. 307.

7 Jakub Mahmudow, Ludobójstwo turkijsko-muzulmańskiej ludności Azerbejdżanu w latach 1918-1920, Warszawa 2019.

140 Ibidem.
} 
niezależnych państw na Kaukazie Południowym w maju 1918 r. Ormianie zaczęli nadawać ton polityczny, wykorzystując fakt, że w pierwszych miesiącach niepodległości rząd Republiki Azerbejdżańskiej był w pełni zaangażowany w wyzwolenie Baku. Ormianie z Karabachu, podżegani przez Demokratyczną Republikę Armenii, utworzyli własne struktury administracyjne pod przewodnictwem Ormiańskiej Rady Narodowej. Również lata 19181920 należą do tragicznych okresów w historii Azerbejdżanu. O tych wydarzeniach opinia światowa, szczególnie europejska, nie miała rzetelnej wiedzy, gdyż, jak pisze autor pracy Ludobójstwo turkijsko-muzułmańskiej ludności Azerbejdżanu w latach 1918-1920141, prawda o okrucieństwach stosowanych przez bolszewików i Ormian przeciwko ludności Azerbejdżanu przez wiele dziesięcioleci epoki radzieckiej była zakazana. Według historyka Yakuba (Jaguba) Mahmudowv, lata te „są dosłownie nasycone krwią dziesiątków tysięcy Azerbejdżan, ofiara agresywnych dążeń Ormian i ich protektorów, którzy stworzyli wszystkie niezbędne warunki polityczne do utworzenia państwa ormiańskiego na historycznych ziemiach Azerbejdżanu. Powyższe fakty, po raz pierwszy pokazujące sytuację polityczną tamtych lat i umożliwiające polityczną ocenę jednej z najtragiczniejszych kart historii Azerbejdżanu XX w., mogły zostać ujawnione dzięki dekretowi prezydenta Hajdara Akijewa z 26 marca 1998 r. „O ludobójstwie dokonanym na Azerbejdżanach”"142.

Dzięki wnikliwym badaniom dokumentów przez Yaguba Mahmudova, dowiadujemy się, iż celem masowej eksterminacji ludności cywilnej Azerbejdżanu - polityki ludobójstwa, genocydu (1918-1920), było unicestwienie szczególnie Azerów. Bolszewicy, w tym Ormianie, realizowali ten zamiar poprzez utworzenie robotniczej Rady Bakijskiej ${ }^{143}$ pod kierownictwem członka największej i najbardziej radykalnej ormiańskiej partii Dasznakcutiun, Stepana Szaumiana, a później przez Demokratyczną Republikę Armenii.

Udostępnienie dokumentów archiwalnych pozwoliło historykom na ich badanie i nagłośnienie prawdy o ludobójstwie turkijsko-muzułmańskiej ludności Azerbejdżanu w latach 1918-1920 przez Ormian. Właśnie praca prof. Yakuba Mahmudova jest cenną pozycją, która na 79 stronach, w czterech rozdziałach przedstawia historię tragicznych wypadków, o których latami historiografia radziecka podawała nieprawdziwe dane i fałszując fakty.

W rozdziale pierwszym, zatytułowanym Ludobójstwo Azerbejdżan w gGuberni bBakijskiej autor opisuje wojskowy sojusz bolszewicki z Ormiańską Radą Narodową w Baku, który kontrolował głównie ormiańskie siły zbrojne. Niewątpliwie bolszewicy celowo przystąpili do sojuszu z Ormianami, grając na ich wrogości do Azerbejdżan i Turków. Ponadto Rada Bakijska otrzymała znaczną pomoc wojskową i finansową z Piotrogrodu. Rada Komisarzy Ludowych Rosji Radzieckiej w lutym 1918 r. wysłała do Baku 30,8 miliona rubli. W pierwszej połowie kwietnia 1918 r., na podstawie ukazu Lenina, wydano rozkaz wysłania

\footnotetext{
${ }^{141}$ Ibidem, s. 79.

142 Z inicjatywy prezydenta H. Aliyewa, w latach 2014-2017 zorganizowano cztery międzynarodowe konferencje, w których wzięli udział znani naukowcy - historycy, politolodzy, socjolodzy itp. Rezultatem obrad jest zbiór referatów wydany w czterech tomach

${ }^{143}$ 12.11.1917 r. bolszewicy i Ormianie, którzy przejęli władzę w Baku, proklamowali tu władzę radziecką. Ustanowili Radę delegatów robotniczych, chłopskich i żołnierskich w Baku z przewodniczącym Ormianinem Stepanem Szaumianem na czele. Dekretem przewodniczącego Rady Komisarzy Ludowych Rosji Radzieckiej, W. Lenina, z 16.12.1917 r. mianowano go Nadzwyczajnym Komisarzem ds. Kaukazu; patrz J. Mahmudow, op. cit, s. 13 .
} 
do Baku 5 tysięcy karabinów, 2 milionów nabojów, 35 karabinów maszynowych. Do Baku została również skierowana grupa okrętów Floty Bałtyckiej pod rozkazami Nadzwyczajnego Komisarza Marynarki Wojennej, W. Połtuchina. Z Moskwy do Baku przybył także 4. Latający Oddział Moskiewski. Bolszewicy szczególnie zadbali o uzbrojenie ormiańskich formacji wojskowych. Podkreślić należy, że znaczna pomoc materialna udzielona została Ormianom przez niektóre kraje Europy Zachodniej, jak np. Wielką Brytanię. Kiedy w końcu marca 1918 r. grupy bolszewicko-dasznackie w Baku dokonały mordu na ludności muzułmańskiej, przedstawiciel misji brytyjskiej w Tyflisie, MacDonell, zaprotestował przed Ormiańską Radą Narodową stwierdzając, że Brytyjczycy popełnili wielki błąd wspierając bolszewików przeciwko muzułmanom. Obwiniał Ormian za wsparcie. Było już jednak za późno. Część ormiańskich formacji zbrojnych, hojnie finansowanych z różnych źródeł, dołączyła do Armii Czerwonej i Rady Komisarzy Ludowych Baku, a następnie pomogła w zdobyciu Baku i guberni bakijskiej w marcu-kwietniu 1918 roku. Tak więc nie tylko ormiańskie formacje narodowe, ale i oddziały Armii Czerwonej brały czynny udział w aktach przemocy przeciwko cywilnym Azerbejdżanom. Formacje dasznacko-bolszewickie Rady Bakijskiej, kierowane przez S. Szaumiana, przeprowadziły na wiosnę 1918 r. „przestępcze, bezprecedensowe w swoim okrucieństwie masowe ludobójstwo narodu azerbejdżańskiego. Dziesiątki tysięcy cywilnych nieuzbrojonych przedstawicieli ludności turkijskomuzułmańskiej azerbejdżańskich Turków, Lezginów, Tatarów, przedstawicieli innych narodowości bez względu na płeć i wiek, w tym dzieci, kobiety, starcy - zostało bezwzględnie zgładzonych tylko ze względu na swoje pochodzenie etniczne. Dasznacy bombardowali muzułmańskie dzielnice Baku z morza i powietrza. . W ciągu zaledwie trzech dni, od 30.03 do 1. 04.1918 r. z rąk ormiańskich, zgodnie z instrukcjami Rady Bakijskiej, zginęło, według różnych źródeł, od 10 do 50 tysięcy cywilnych Azerbejdżan.

Ważnym wkładem w badanie tych wydarzeń były udostępnione materiały Nadzwyczajnej Komisji Śledczej Republiki Azerbejdżanu, utworzonej 15 lipca 1918 r. w celu zbadania faktów dotyczących przemocy wobec ludności muzułmańskiej oraz w odniesieniu do ich własności na Kaukazie Południowym od czasu rozpoczęcia pierwszej wojny światowej. Przez cały okres działania tej Komisji Śledczej (do 1.11.1919 r.) zebrano materiały składające się z 36 tomów i 3500 stron, które dotyczyły wszystkich ówczesnych regionów Azerbejdżanu. Komisja ta zebrała szczegółowe materiały na temat zbrodni Ormian na Azerbejdżanach guberni gandżyjskiej. Raport M.M. Michajłowa, przewodniczącego Komisji ds. Badania Zbrodni Ormiańskich Band Zbrojnych Przeciwko Muzułmańskiej Ludności Cywilnej w Karabachu i Zangezurze, Zamieszczony w książce Yakuba Mahmudova raport M.M. Michajłowa odgrywa ważną rolę w przywracaniu prawdziwego obrazu tych krwawych wydarzeń.

W drugim rozdziale książki, zatytułowanym Ludobójstwo Azerbejdżan w guberni gandżyjskiej (1918-1920), autor powołuje się na protokoły z obrad ówczesnego parlamentu Republiki Azerbejdżanu (1918-1920), telegramy przywódców rządowych, korespondencję ministerstw spraw zagranicznych, wewnętrznych, organizacji charytatywnych, przedstawicieli dyplomatycznych Republiki Azerbejdżanu w Gruzji i Armenii. Dokumenty te zawierają obszerny materiał faktograficzny dotyczących zamiaru zniszczenia ludności muzułmańskiej, aktywnego udziału w tych akcjach sił zbrojnych Republiki Armenii i nielegalnych ormiańskich oddziałów wojskowych. 
Wspomniana powyżej Narodowa Komisja Śledcza zebrała szczegółowe materiały dotyczące ludobójstwa Azerbejdżan w guberni gandżyjskiej. Właśnie we wspomnianym raporcie M.M. Michajłowa podane są przykłady aktów przemocy stosowanych wobec Azerbejdżan w ujezdach dżewanszyrskim, szuszeńskim i dżabrailskim. Raport ten odegrał ważną rolę w przywracaniu prawdziwego obrazu wydarzeń. M.M. Michajłow prowadził prace śledcze w czterech ujazdach guberni gandżyjskiej, w których muzułmańska ludność była systematycznie eksterminowana przez długi czas przez lokalne ormiańskie bandy i regularne jednostki wojskowe dasznackiej Armenii.

Rozdział Ludobójstwo Azerbejdżan w guberni erywańskiej (1918-1920) zawiera informacje zaczerpnięte $\mathrm{z}$ dokumentów znajdujących się w archiwach Azerbejdżanu, Turcji, Wielkiej Brytanii i innych. Wspomnienia ówczesnych polityków, wśród których nie brakuje Ormian, umożliwiają odtworzenie strasznego obrazu ludobójstwa dokonanego przez ormiańskie formacje zbrojne przeciwko ludności turkijsko-muzułmańskiej w guberni erywańskiej w latach 19181920: „Tragiczne wydarzenia na wyżej wymienionym terytorium zaczęły się jednocześnie $\mathrm{z}$ wypadkami w guberni bakijskiej. Uzbrojone po zęby oddziały ormiańskie, mające bogate doświadczenie w eksterminacji ludności turkijsko-muzułmańskiej we Wschodniej Anatolii zdobyte w czasie I wojny światowej, wycofując się wraz z armią rosyjską powracającą z frontu kaukaskiego podjęły na początku 1918 r. działania zbrojne w celu oczyszczania z muzułmańskiej ludności terytorium guberni erywańskiej. Według kalendarza kaukaskiego na 1917 rok liczba muzułmanów w guberni erywańskiej wynosiła 423123 (37,7\%) osoby. Muzułmanie stanowili większość w trzech z siedmiu ujezdów tej guberni (nachiczewański - 50\%, szarursko-daralageski - 66,7\%, surmalijski 63,6\%)".

Fizyczna eksterminacja cywilów, masakry, okrucieństwa itp. wszystko to zostało użyte przez Ormian, by zmusić rdzenną ludność do opuszczenia ziem, na których żyli ich przodkowie przez wieki. Jak pisze autor: „,W ten sposób stworzono sztucznie centrum życia Ormian, które stale powiększało się wraz z napływem uchodźców ormiańskich z Turcji. Zalali ujezdy dziesiątkami i setkami tysięcy rosyjskich Ormian".

29 maja 1918 r. po raz pierwszy na Kaukazie Południowym, na terytorium guberni erywańskiej powstało państwo ormiańskie, Demokratyczna Republika Armenii. Na mocy ustnego porozumienia między przedstawicielami osmańskiej Turcji i Azerbejdżanu, dotyczącego powstania państwa ormiańskiego, 29 maja 1918 r. w Batumi doszło na mocy traktatu do przekazania przez Azerbejdżan terytoriów azerbejdżańskich wraz $\mathrm{z}$ miastem Erywań (z wyjątkami): ujezd nowobajazydzki, ujezd erywański, ujezd eczmiadzyński, ujezd aleksandropolski ( $\mathrm{z}$ wyjątkiem centrum Aleksandropola). W ten sposób nowo utworzona Republika Armenii objęła wąski obszar górski między jeziorem Gojcze (Sewan) a nowymi granicami państwa osmańskiego. Łączna powierzchnia terenów przekazanych Republice Armenii wynosiła $9000 \mathrm{~km}^{2}$. Liczebność populacji na tych terenach wynosiła wówczas 321 tys. w tym 239 tys. stanowili napływowi Ormianie, 80 tys. turkijscy muzułmanie, a 11 tys. inne narody. Podczas rozmów na konferencji w Batumii (11 maja4 czerwca 1918), które doprowadziły do powstania Demokratycznej Republiki Armenii, strona ormiańska, w zamian za przekazanie jej ziem Azerbejdżanu w celu utworzenia państwa, przyjęła szereg zobowiązań wobec Azerbejdżanu i Turcji. Te ustalenia przyjęte przez Ormian zostały zagwarantowane w Batumi, w traktacie „O pokoju i przyjaźni” z 4 czerwca 1918 r. między Imperium Osmańskim a Republiką Armenii. Jednak zaraz po zakończeniu rozmów w Batumi 
i powstaniu Demokratycznej Republiki Armenii Ormianie odmówili wypełniania swoich zobowiązań. Rozpoczęli (tak jak przed majem 1918 r.) akcję ludobójstwa Azerbejdżan na poziomie państwowym, rozszerzając jej zasięg geograficzny i wkraczając na terytorium gandżyjskiej guberni Republiki Azerbejdżanu.

Odstąpienie przez rząd azerbejdżański w maju 1918 r. miasta Erywań jako stolicy Armenii miało tragiczny wpływ na los muzułmańskiej ludności miasta. Ogólnie rzecz biorąc autor pracy uważa, że okres istnienia Demokratycznej Republiki Armenii w latach 19181920 dobitnie pokazał, że Ormianie, którzy szczycili się „cywilizacją” i „starożytną historią”, w rzeczywistości po prostu nie dojrzeli, aby mieć własne państwo, a tym bardziej kontrolę nad innymi narodami. Po sowietyzacji Armenii w 1920 r. krwawe wojny z poprzednich lat zniknęły na długi czas. Moskwa odzyskała rolę arbitra $\mathrm{w}$ sporach międzynarodowych. Konflikt przycichł, ale nie wygasł. Kolejna fala ormiańskiej agresji przeciwko Azerbejdżanowi nastąpiła pod koniec XX wieku.

W ostatnim rozdziale pracy Jakuba Mahmudowa Ludobójstwo ludności turkijskomuzutmańskiej we Wschodniej Anatolii, w regionach: urmijskim, chojskim, salmaskim $i$ innych $w$ latach 1914-1920, badacz przedstawia sytuację, o której powszechna historia wspominała lakonicznie, a z dokumentów wynika, że ludobójstwo dokonane przez Ormian na ludności turkijsko-muzułmańskiej obejmowało wszystkie regiony wchodzące w skład „przestrzeni wymyślonej przez ormiańskich nacjonalistów Wielkiej Armenii. Ideolodzy i praktycy ormiańskiego szowinizmu rozpoczęli eksterminację lokalnej ludności turkijskomuzułmańskiej w tych regionach i obwodach Azerbejdżanu i Turcji, które stanowiły przedmiot nieuzasadnionych roszczeń terytorialnych: Wielkiego Ormiaństwa". Takimi regionami była właśnie Wschodnia Anatolia i regiony południowego Azerbejdżanu, których ludność została poddana niespotykanej przemocy i aktom ludobójstwa, dokonanym przez ormiańskich nacjonalistów. Potwierdzają to liczne dokumenty archiwalne. Na przykład Osmańskiego Archiwum Rządowego (BOA) świadczą o ludobójstwie turkijskomuzułmańskiej ludności Vanu, Erzurumu, Trabzonu i innych miast w regionie w latach 19141920.

W momencie wybuchu pierwszej wojny światowej Ormianie zaczęli bezpośrednio atakować i realizować plan masowej eksterminacji ludności turkijsko-muzułmańskiej we Wschodniej Anatolii. Korzystając z wysiłków państw ententy, by zniszczyć Imperium Osmańskie i podzielić jego terytoria, Ormianie występowali jako instrument polityki wielkich mocarstw, licząc na stworzenie państwa ormiańskiego na ziemiach tureckich. Spekulacja Ormian oparła się na poparciu ze strony Imperium Rosyjskiego, a następnie Rosji Radzieckiej. Podczas pierwszej wojny światowej wojska rosyjskie najechały na terytorium Imperium Osmańskiego - Wschodnią Anatolię. Ormiańskie komitety narodowe, stawiające się w pozycji przedstawicieli ormiańskiej mniejszości etnicznej, wywołały bunt przeciwko państwu osmańskiemu. Ormiańskie oddziały wojskowe terroryzowały cywilną ludność turkijską, nie oszczędzając starców, dzieci, kobiet.

Dziesiątki tysięcy mieszkańców regionu - Turków osmańskich, Azerbejdżan, zostało zabitych przez ormiańskie formacje wojskowe tylko ze względu na pochodzenie etniczne. Ludobójstwo Turków Vanu trwało kilka dni. Ogółem w latach 19151916 w mieście tym i okolicach zginęło ponad 50 tys. osób. Ormiańscy nacjonaliści zamierzali zająć miasto Erzurum i okolice. Wraz z początkiem pierwszej wojny światowej Ormianie z Erzurumu i 
Beyazitu, dezerterując $\mathrm{z}$ armii osmańskiej, przeszli na stronę Rosji i stali się trzonem tworzonych (wspomnianych wcześniej) ormiańskich sił ochotniczych, które rozpoczęły eksterminację muzułmańskiej ludności Erzurumu.

W latach 1914-1921 ormiańscy bojownicy zgładzili około 30 tys. cywili z Karsu i Ardahanu. Tylko w 1920 r. Ormianie przeprowadzili brutalną czystkę czterech tysięcy mieszkańców karskich wiosek.

Ormiańską polityką ludobójstwa można też tłumaczyć masową eksterminację mieszkańców muzułmańskich północnych regionów Iranu - południowej części historycznego Azerbejdżanu ${ }^{144}$.

Do tej pory świat, mając niepełne, jednostronne (ormiańskie) informacje mylnie interpretował wydarzenia na Zakaukaziu, ale dzięki prowadzonym przez Instytut Historii ANAN w Baku badaniom naukowym, organizowanym międzynarodowym konferencjom, nagłaśnianiu i uświadamianiu opinii publicznej skrywanego przez lata problemu jest szansa, by doprowadzić do ujawnienia wszystkich tragicznych zaszłości i pozwolić na sprawiedliwą ocenę. Poznanie prawdy, ujawnienie dokumentów, którymi dysponują obie strony, może doprowadzić do pojednania zwaśnionych państw.

\section{Streszczenie:}

Artykuł skupia się na analizie stosunków azerbejdżańsko-ormiańskich w latach 1918-1920 oraz opisuje najważniejsze wydarzenia $\mathrm{w}$ tym okresie $\mathrm{m}$. in. o ludobójstwie turkijskomuzułmańskiej, ludobójstwo Azerbejdżan w Guberni itd. Cały artykuł opisany jest z punktu widzenia historyka Yakuba Mahmudova, na bazie jego badań i analiz.

\footnotetext{
${ }^{144}$ Y. Mahmudow we Wstępie pisze, że opracowano projekty decyzji o wszczęciu postępowania karnego przeciwko 194 osobom, głównie narodowości ormiańskiej, oskarżonym o różne zbrodnie popełnione przeciwko muzułmanom w Baku i ujeździe bakijskim, mieście Quba i ujeździe kubińskim, mieście Szamachy i ujeździe szamachijskim, ujeździe geokczajskim, guberni bakijskiej, ujeździe areskim, nuchińskim, dżabrailskim, szuszyńskim i zangezurskim guberni gandżyjskiej Azerbejdżanu. Położenie geograficzne i polityczne kraju pozwalało, by na początku $1918 \mathrm{r}$. teren ten stopniowo przekształcał się w „regionalne centrum działań bolszewickich i ormiańskich nacjonalistycznych partii, był miejscem rozlokowania tysięcy rosyjskich i ormiańskich żołnierzy powracających $\mathrm{z}$ frontów na Bliskim Wschodzie i Kaukazie, i osiedlających się w miastach Azerbejdżanu, szczególnie w Baku, zamieszkałym w większości (183.000 muzułmanów) przez rodzimą ludność. Stworzenie sojuszu bolszewicko-ormiańskiego pozwoliło na proklamowanie władzy radzieckiej (2.11.1917 r.), która wraz z Ormianami zaczęła prześladowania rodzimej ludności Baku i okolic. Szczególną rolę odegrała w tym procederze Rada Bakijska pod przewodnictwem Ormianina Stepana Szaumiana". Patrz: J. Mahmudow, Wstęp, op. cit.
} 


\section{Słowa kluczowe:}

Stosunki azerbejdżańsko-ormiańskie, ludobójstwo

Key words:

Azerbaijani-Armenian relations, genocide

\section{Bibliografia:}

1. Estern partnership za:

https://www.consilium.europa.eu/pl/policies/easternpartnership/azerbaijan/ (02.07.2020).

2. Górski karabach za: ttps://warsawinstitute.org/pl/gorski-karabach-bez-widokownaprzelom/(02.07.2020).

3. Mahmudov Y, Azerbaijan, Short History of Statehood, Baku 2006, s. 122-152.

4. Mahmudow J., Ludobójstwo turkijsko-muzułmańskiej ludności Azerbejdżanu w latach 1918-1920, Warszawa 2019.

5. Rayfield D., Edge of Empires. A History of Georgia, 2012, s. 307. 
